\title{
Dos quadros de guerra à participação: notas sobre a jornada do refúgio palestino em São Paulo
}

L Helena de Morais Manfrinato

Universidade de São Paulo, São Paulo,São Paulo,Brasil

Dol 10.11606/issn.2316-9133.v25i25p421-436

resumo Neste trabalho, enfoco a experiência do refúgio de famílias palestinas em uma ocupação urbana em São Paulo, a partir da sua projeção pública após a repercussão da foto do menino Aylan, em uma tentativa malsucedida de chegar à Europa. A comoção pública levou muitos brasileiros até a ocupação, oferecendo diversos tipos de ajuda, movidos por um forte sentimento humanitário. Os enquadramentos daí surgidos modelaram os modos pelos quais os refugiados vêm participando das suas relações no Brasil. Por sua vez, estes agenciam essa visibilidade através de suas próprias pautas políticas, como o Direito de Retorno, contestando a imagem de precariedade vinculada ao refúgio e tecendo coalizões com imigrantes e refugiados de outras nacionalidades. Meu objetivo é analisar alguns agenciamentos do refúgio e como esses(as) palestinos(as) vêm produzindo suas próprias formas de participação nessas relações, através da alimentação e da criação de novos espaços políticos e de moradia.

palavras-chave Refúgio; Palestinos;Ocupação urbana; Quadros de guerra.

From the war frames to participation: notes on the journey of Palestinian refuge in São Paulo

abstract In this paper, I focus on the experience of the refuge of Palestinian families in an urban occupation in São Paulo, from their public projection after the repercussion of the photo of the boy Aylan, inan unsuccessful attempt to reach Europe. The public commotion led many Brazilians to the occupation, offering diverse types of help, moved by a strong humanitarian feeling. The frameworks that emerged shaped the ways refugees have been participating in their relations in Brazil. These, in turn, guidethis visibility through their own political guidelines, such as the Right of Return, contesting the image of precariousness linked to the refuge, and weaving coalitions with immigrants and refugees of other na- 
tionalities. My purpose is to look at some settlements in the refuge, and how these Palestinians have been producing their own forms of participation in these relations through food, and the creation of new political spaces and housing.

keywords Refuge; Palestinians; Urban occupation; War frames.

\section{Introdução}

Tem aqui muitos jovens refugiados palestinos. Eles nasceram na Síria, mas, veja bem, não possuem os direitos plenos de um cidadão sírio. Eles são refugiados palestinos dentro da Síria, são apátridas e querem voltar, querem que seja efetivado o direito de retorno para a Palestina histórica, que é consagrado na resolução 194 da ONU, então, o direito internacional prevê isso, mas a questão é totalmente política. Eles não podem voltar.

(Henrique Sanchez, membro do coletivo Movimento Palestina para Tod@s, em entrevista a Caio Castor, outubro de 2015 ${ }^{1}$.)

A fala acima foi proferida durante as "Jornadas de Yarmouk", ${ }^{2}$ em outubro de 2015, na Ocupação Leila Khaled. O evento lançou a Ocupação publicamente e foi organizado em torno do tema do refúgio dos (as) palestinos(as) que vieram ao Brasil fugindo da Guerra da Síria. O Retorno - Al-'Awda-, uma reivindicação e um direito dos palestinos que foram expulsos de suas terras após a criação do Estado de Israel, em 1948 - a chamada $\mathrm{Al}-\mathrm{Nakba}^{3}$-, continua sendo um sonho e um objetivo para seus filhos, netos e bisnetos. Os palestinos que vieram ao Brasil e acabaram por se instalar na ocupação são duplamente refugiados: já o eram nos campos palestinos na Síria e hoje o são no Brasil. As narrativas versaram sobre a vida nos campos, a destruição perpetrada pela guerra e a denúncia dos responsáveis por seus múltiplos deslocamentos. Alguns deles organizaram a venda de comidas para os participantes, que fluíam de uma sala a outra segurando shawarmas e sajs, feitos num forno convexo emprestado de conhecidos do Brás. ${ }^{4}$

\footnotetext{
${ }^{1}$ Em: https://www.youtube.com/watch?v=u39HjYy28iM. Acesso em: fevereiro de 2017.

${ }^{2} \mathrm{O}$ evento teve ainda o lançamento do livro A origem do Estado Islâmico, do jornalista John Cockburn, e a participação do jornalista e refugiado palestino Abu Saleh, o professor de relações internacionais da PUC-SP Reginaldo Nasser, o jornalista José Arbex Jr. e o fotojornalista e cinegrafista Gabriel Chaim, que cobriu o conflito na Síria.

3 "Catástrofe", em árabe.

${ }^{4} \mathrm{O}$ Brás é um bairro de antiga ocupação árabe-islâmica e hoje concentra parte das instituições e mesquitas islâmicas em São Paulo. É um dos lugares para onde afluem os novos migrantes árabe-
} 
O evento foi um enorme sucesso: estiveram presentes representantes de mídias independentes, intelectuais envolvidos com as questões médio-orientais, ONGs de apoio a imigrantes e refugiados, estudantes, libaneses, sírios, palestinos já estabelecidos no país e brasileiros.

Os presentes manifestaram uma disposição entusiástica para entender a questão palestina, quem eram os refugiados vindos da Síria, mas, sobretudo, ajudar no que fosse preciso. Foram feitas doações de alimento, roupas, dinheiro, mobília e eletrodomésticos. Foi oferecida ajuda para matricular as crianças nas escolas da região, além de atendimento médico, psicológico e aulas de português. Muitos jornalistas se puseram à disposição para produzir matérias, e estudantes de relações internacionais ofereceram propostas de atividades com os refugiados. Ao conversar com os participantes, percebi que havia uma comoção generalizada- e não mencionada durante os debates - pela morte de uma criança síria que, dias antes havia se afogado tentando fazer a travessia com a família para a Europa. Para essas pessoas, a terrível imagem do bebê sendo resgatado sem vida na orla de uma praia turca havia transformado o descolamento populacional ${ }^{5}$ decorrente da guerra na Síria em uma crise humanitária.

As jornadas, marcadas pelo signo do sofrimento de guerra e o drama do refúgio foram um marco na configuração das relações entre os palestinos da ocupação e a mídia, o poder público e as ONGs de apoio aos migrantes e refugiados. Por sua vez, a intensa visibilidade e oferecimento de ajuda aos refugiados colocaram novas demandas políticas e desafios aos militantes e moradores brasileiros. A repercussão das jornadas foi uma surpresa para todos, que nunca haviam imaginado tamanha repercussão pública, ainda que seu arranjo - refugiados palestinos e famílias brasileiras - fosse inusitado. $\mathrm{O}$ prédio ${ }^{6}$ passou por diversas tentativas de ocupação até princípios de julho de 2015, quando o Terra Livre, ${ }^{7}$ um movimento nacional de moradia que atua no campo e na cidade, o ocupou. No ano de 2014, conforme relato de um de seus militantes, o movimento decidiu que era preciso ter uma ocupação no centro ${ }^{8}$ de São Paulo, de onde

muçulmanos, onde está a mesquita, os sheikhs, os empregadores árabes e a rede de solidariedade que acionam quando algum(a) árabe precisa de ajuda.

${ }^{5}$ Essa população aflui principalmente para os países vizinhos à Síria, como Turquia, Líbano e Jordânia, que já receberam até 2015, respectivamente, 2 milhões, 1 milhão, e 600 mil pessoas. Os jornais vêm noticiando esse deslocamento e como os diversos países vêm recepcionando essa população, com destaque para os países europeus e alguns dos seus efeitos perversos, como o afogamento de refugiados, mortes de dezenas de pessoas dentro de containers que os transportam por longas distâncias e o atravessamento de fronteiras policiadas.

${ }^{6} \mathrm{O}$ prédio, abandonado há quinze anos, pertenceu no passado à Telesp.

${ }^{7}$ Fundado em 2008 a partir de um racha da corrente do PSOL "Terra, Trabalho e Liberdade", o movimento atua hoje em Goiás, onde tem mais de 30 ocupações, ultrapassando a atuação do MST naquele estado. Na cidade de São Paulo, possui ocupações no Jardim Pantanal e em Pinheiros, e nas cidades de Cotia e Osasco, na grande São Paulo, somando hoje mais de 2 mil pessoas em suas ocupações.

${ }^{8}$ Recentemente, o centro se tornou uma prioridade para o movimento, alinhando-se aos movi- 
veio a iniciativa de ocupar o prédio na Liberdade, ${ }^{9}$ em princípio apenas para famílias brasileiras.

Nesse período, um dos militantes e fundadores do Movimento Palestina para Tod@ $\mathrm{s}^{10}$ e parceiro do Terra Livre, Hasan Zarif, soube que famílias palestinas vindas da Síria ${ }^{11}$ estavam vivendo em pensões precárias e caras no Brás, Guarulhos e outras localidades em São Paulo. O contato com o Terra Livre vinha da experiência política de alguns membros com militantes do PSOL e de sua participação no Comitê Popular da Copa, frente formada em razão dos impactos políticos, sociais e econômicos do megaevento esportivo. ${ }^{12}$ Sabendo da nova ocupação realizada no bairro da Liberdade e da importância estratégica do centro para os/as refugiados(as) - onde têm acesso a empregos, escolas, hospitais e ONGs de apoio -, Hasan pediu ao movimento que lhes dessem algum espaço. Em pouco tempo, sessenta palestinos (as) afluíram para a ocupação, tomando quatro andares do antigo prédio comercial.

A escolha do nome da ocupação - Leila Khaled - foi uma sugestão de uma das militantes do Terra Livre, que em assembleia fez uma exposição sobre a luta da guerrilheira palestina. ${ }^{13}$ Ela me relatou o assombro que sentiu quando entrou no prédio e viu a primeira família chegar, "uma mulher, de véu e roupas pretas, com as malas e os filhos. Aquilo que impactou muito. Era inacreditável”. Aos poucos, a presença das famílias palestinas começou a se fazer notar na constituição dos espaços, que foram tomando forma: os adesivos com a frase "I Love Allah" nas portas dos seus apartamentos, os escritos em árabe nas paredes dos espaços comuns e elevadores, o cheiro dos temperos árabes tomando os anda-

mentos de moradia que pautam o acesso aos equipamentos urbanos, que, em São Paulo, concentram-se nessa região da cidade. Ver Carlos Filadelfo (2010).

${ }^{9}$ Eles me relataram que o prédio em questão já havia sido ocupado por pouco tempo pela Frente de Luta por Moradia (FLM), mas abandonado rapidamente.

${ }^{10}$ Movimento fundado em 2009 para oferecer apoio aos refugiados palestinos reassentados no Brasil, por conta da Guerra do Iraque e da realocação da sua população palestina em campos nos territórios fronteiriços. Faço parte desse movimento desde 2013, de modo que minha incursão na ocupação se deu, primeiramente, como militante. Essa transição não será objeto da presente reflexão.

${ }^{11}$ A Guerra da Síria começou no bojo do levante popular árabe conhecido como Primavera Árabe, em 2011. O conflito se complexificou e se aprofundou, transformando-se numa guerra civil que já tirou centenas de milhares de vidas, além de causar o deslocamento mais de 11 milhões de pessoas, internamente e para fora do país.

${ }^{12}$ O comitê, surgido em 2011, é uma rede de articulação horizontal e apartidária. Enfatizou o impacto da reestruturação urbana pela qual as cidades que sediariam a copa precisariam passar, incluindo as inevitáveis remoções da população mais pobre ou em situação de rua, bem como a violência contra os/as ambulantes. Desse modo, os movimentos de moradia, e moradores(as) de assentamentos e ocupações estiveram presentes em peso, além de movimentos anarquistas, feministas, ambulantes, grupos de teatro, ONGS de direitos humanos, pastorais sociais, entre outros. O Mop@t em especial pautou a compra de equipamentos militares israelenses pelo governo brasileiro, além de apoiar as principais pautas do comitê.

${ }^{13}$ Leila Khaled é uma guerrilheira palestina que ficou famosa nos anos 1970 por conta de algumas operações no âmbito da organização Frente Popular para a Libertação da Palestina. 
res nas horas das refeições. As preferências e primeiras simpatias também vão se estabelecendo na convivência: um dos brasileiros, que se tornou um grande amigo dos palestinos, instituiu o arabiano - "uma mistura de árabe com baiano" -, com o qual se comunicava com eles e traduzia as perguntas dos jornalistas. $\mathrm{O}$ espaço passou a ser intensamente visitado por jornalistas, estudantes e ONGs que vinham entrevistar os refugiados, oferecer suporte e realizar suas pesquisas.

A primeira vez que subi as escadas escuras do prédio, meio arfante pela falta de hábito e condicionamento físico, foi em setembro de 2015. Numa sala ampla de um antigo escritório comercial cuja vista dava para prédios residenciais no bairro do Glicério, eu vi camas e colchões ladeados, e malas espalhadas pelos cantos. Olhei ao redor e vi um dos refugiados - um sírio ${ }^{14}$ - perto de sua cama, se preparando para fazer a oração do $I s h a,{ }^{15}$ a quinta e última oração islâmica do dia. Alguns deles me cumprimentam com um aceno de cabeça. Vi jovenzinhos de quase vinte anos perambulando em grupo por ali, rindo, fumando seus cigarros Eight de filtro vermelho e mexendo em seus celulares. Espiavam com curiosidade e um sorriso tímido, as brasileiras que ali estavam. Nesse ambiente, o Movimento Palestina para Tod@s discutiu as necessidades de primeira ordem, isto é, a regulamentação e apoio jurídico aos refugiados, as possibilidades de trabalho e como conseguir móveis e eletrodomésticos para os apartamentos. Foi após o evento de lançamento que a administração da intensa procura dos jornalistas para realizar matérias na ocupação tornou-se objeto de preocupação do movimento.

O modo como grande parte dos jornalistas abordava o refúgio em suas matérias lançava mão do drama da destruição da guerra na vida das famílias, os impactos interculturais e as dificuldades no Brasil. Eles lhes perguntavam sobre a vida nos campos, o desmembramento de suas famílias e as dificuldades de travessia desde o país de origem. As perguntas visavam comover os refugiados com o fito de produzir relatos dramáticos para as suas matérias. Não apenas as mesmas perguntas se repetiam, mas o esforço para provocar um certo estado emocional nos entrevistados, como a evocar os ecos dos horrores sofridos antes do refúgio no Brasil. Em minha experiência de pesquisa ${ }^{16}$ pude constatar que os temas concernentes ao Oriente Médio e ao Islã são transmitidos a partir de um enquadramento orientalista, ${ }^{17}$ sendo notável a repetição dos temas do "terroris-

\footnotetext{
${ }^{14}$ A população árabe na ocupação era composta majoritariamente por palestinos(as). Mas também passaram por ali sírios, egípcios, marroquinos e libaneses.

${ }^{15}$ As palavras em árabe bem como os conceitos nativos serão grafados em itálico. As citações mais longas dos(as) autores(as) serão marcadas por aspas duplas.

${ }^{16}$ Islã, mídia e direitos humanos: políticas de representação e visibilidade a partir do agenciamento de uma rede de instituições islâmicas no pós-onze de setembro. Dissertação defendida em 2015, no PPGAS-USP.

${ }^{17}$ Por enquadramento refiro-me à discussão que Judith Butler realiza em Quadros de guerra, que diz que a nossa capacidade de reagir com indignação, antagonismo e crítica dependerá, em parte, de como a norma diferencial do humano é comunicada através dos enquadramentos visuais e
} 
mo islâmico" e da "opressão da mulher muçulmana". Nesse novo contexto discursivo, essas imagens de violência aparecem de vez em quando, mas o principal foco é outro: a vida nua imposta pela guerra e pobreza, expressa num tom que mescla piedade e complacência.

Em novembro de 2015, um dos palestinos estava dando uma entrevista em sua casa, também transformada em uma cozinha industrial, com dois fornos grandes, um longo balcão com pia e uma estante para mantimentos. O jornalista, em dado momento, lhe perguntou: "Antes você era pintor e agora é doceiro. O que acha disso?”.Ao que ele respondeu, virando a forma de doces em direção ao jornalista, "Essa é a minha tela, essas são minhas tintas [morde o doce] e esse sabor é a minha arte”. A resposta deixou o jornalista desconcertado, e não foi incluída no resultado final da matéria. De maneira correlata, os/as refugiados(as) são questionados sobre o modo como chegam ao Brasil e sobre os efeitos da guerra, com a destruição de suas casas, cidades e a separação das famílias. O tom usado é o mesmo do ilustrado acima: visa comover o entrevistado a respeito de sua condição precária e altamente vulnerável. Seu sofrimento é tema da maior parte das entrevistas que concedem, motivo pelo qual expressam cansaço e desagrado. Aos poucos, vão percebendo a insistência dos jornalistas em termos de exploração de sua imagem, a partir de referenciais que os/as incomodam e com excessiva exposição.

O enquadramento da vulnerabilidade do refúgio não se limita à cobertura midiática, mas se estende também à ajuda oferecida aos refugiados. Ela é posta, de modo mais ou menos explícito, em termos assimétricos, entre aqueles que têm uma vida digna e aqueles que não a têm, e de quem se espera retribuição em forma de gratidão; uma gratidão que evoca a condição assimétrica em que a relação é estabelecida. Ouvindo muitos voluntários, pude perceber irritação pela falta de gratidão de alguns refugiados aos quais era oferecida ajuda ou, então, uma sensação de satisfação pela gratidão expressa, pois entendiam estar fazendo o bem a quem precisava. No caso dos(as) palestinos(as), opera no imaginário desses brasileiros a condição de refúgio anterior à Guerra da Síria, imposta pela ocupação israelense, um povo exposto a um longo martírio que os vitimou por décadas. "Todos nos tratam como se precisássemos de ajuda o tempo todo", me disse Ammar ${ }^{18}$.

As relações em que se inserem os refugiados palestinos estão se estruturando em torno dessas concepções de refúgio, bem como da intensa exposição pública dos refugiados, que condicionam os tipos de engajamento de cada um, seja do

discursivos (BUTLER, 2015, p. 118). Aqui, refiro-me a um tipo de enquadramento que pode ser visual e/ou discursivo, cujos referenciais condicionantes são orientalistas (SAID, 2003), isto é, supõe um "outro" violento, opressor/oprimido, anti-moderno, isto é, contrário aos pressupostos ocidentais de liberdades sociais, civis, políticas e de pensamento.

${ }^{18}$ Alguns dos nomes dos meus interlocutores foram substituídos por nomes fictícios, para preservar seu anonimato. 
Estado, dos militantes, dos moradores, das ONGs oudos jornalistas. Nesse sentido, procurarei analisar alguns dos arranjos políticos oriundos da experiência pública da ocupação Leila Khaled e mostrar como essa condição limitou, mas também estendeu, a participação deles para outros espaços políticos.

\section{Enquadramentos}

A comoção causada pelas imagens midiáticas de um conflito pode promover - ou não - ações compassivas por parte dos que assistem de longe aos horrores sofridos por outros povos (SONTAG, 2003). Entre a comoção diante do sofrimento alheio e a ação no sentido de mitigá-lo há uma distância considerável, que depende, entre outros fatores, de quem está sofrendo e como seu sofrimento está sendo enquadrado. Esses dois fatores devem vir acompanhados de intensa visibilidade e alcance de circulação, para que se torne um evento capaz de alterar a percepção dos receptores sobre determinada questão e fazer emergir uma consciência política sobre ela. É preciso, para isso, que o enquadramento em circulação rompa com o contexto original em que foi formado para que assim chegue a outro lugar (BUTLER, 2015) e estabeleça a "hegemonia do enquadramento”. Segundo a autora, é a necessária estrutura iterável do enquadramento que fornece a ele novas possibilidades de trajetórias de comoção, que podem ser diversas, a depender dos novos contextos de recepção. Isso quer dizer que o impacto das imagens públicas num mundo em que a política depende de sua incessante fabricação e repetição, pode ser variável e produzir arranjos inusitados.

Em um diálogo imaginado com Susan Sontag, Butler se pergunta o que seria necessário a uma imagem para que o caráter precário das vidas perdidas na guerra impactasse o receptor a ponto de despertar uma consciência ética e política sobre a guerra. Em outras palavras, ela quer saber como a comoção é produzida pelo enquadramento e como ela impacta o julgamento e a prática ética e política. Sontag termina seu ensaio de modo ambivalente a respeito da eficiência das fotografias em seu papel dedespertar o clamor das pessoas contra a guerra, a julgar pela excessiva violência sensacionalista a que estamos todos expostos. Em um tempo em que a violência é transformada em forma de entretenimento e está excessivamente presente nas formas ficcionais que consumimos, é possível que uma fotografia levante esse clamor? Sontag acredita que mais do que chocar, a fotografia deve apelar ao nosso senso de obrigação moral: o choque se converteu num clichê a ser consumido como uma demanda de mercado, o que teria deteriorado nossa capacidade de reação ética e interpretação política. A fotografia mobilizaria sentimentos mais do que o raciocínio, continua Butler em sua interpretação de Sontag, o que nublaria o julgamento dos receptores acerca dos acontecimentos que provocaram o horror fotografado.

As guerras do século XX transformaram a fotografia na condição e articulação da indignação pública (BUTLER, 2015, p. 126). Sobretudo após a Primeira 
Guerra Mundial, ela assume a condição de verificação de verdade sobre uma atrocidade ocorrida alhures, assim como de sua legibilidade. Se uma fotografia nos impacta e nos tira o sono é porque se verificou, de fato, uma perda, isto é, estamos diante de uma vida passível de luto. Sua potência política e ética consiste em denunciar os injustificados argumentos civilizatórios e humanitários da guerra e nos impelir a uma reação. Tanto Sontag quanto Butler apontam que as disposições afetivas e cognitivas operando simultaneamente na recepção e interpretação da fotografia de guerra são a chave para nos impelir a realizar uma ação ética e política. Espera-se que a fotografia desperte o receptor para a irracionalidade da guerra e o engaje eticamente no sentido de mitigar o sofrimento do outro.

Recentemente, ao conversar com uma médica que participou de alguns mutirões para refugiados, ouvi dela que foi a imagem do garotinho na praia turca que a levou a oferecer ajuda aos refugiados que ali estavam. Procurou as organizações e conheceu médicos(as) que já faziam o trabalho voluntário, disponibilizando seus serviços. Eu contei a ela sobre a experiência das jornadas e que eu havia percebido uma comoção generalizada diante daquela fotografia e uma enorme vontade de ajudar as pessoas que, como Aylan, havia sofrido e perecido com a Guerra. Ela desviou seu olhar para longe e confirmou com a cabeça: "Nós jamais nos recuperaremos daquilo", me disse. Havia as pessoas que queriam saber das histórias por trás do refúgio, e dar-lhes visibilidade de um jeito que não havia tido precedente nas mídias, redes sociais e espaços de debate público. Mas havia aqueles que sentiam uma necessidade de ajudar e acolher essas pessoas, e saber que parte delas estava em São Paulo lhes dava capacidade para a ação diante daquela injustiça.

No final de 2015, acompanhei o "São Paulo Migrantes", um ciclo de palestras sobre o tema da migração na capital paulista, em que falaram intelectuais, imigrantes, refugiados, representantes de ONGs e do Estado sobre o atual tema do refúgio na cidade. Numa das palestras, sobre mídia e migração, a repercussão exaustiva da imagem da criança foi apontada com uma dos elementos responsáveis por catapultar a guerra da Síria internacionalmente como uma crise humanitária. Nas redes sociais, as pessoas trocaram suas fotos de perfil, e uma enorme quantidade de charges foi produzida e circulada, com Aylan recolocado em outros cenários, ou como um anjo no céu, ou dormindo em sua cama, na mesma posição e com as mesmas roupas em que foi encontrado na praia. Seu corpo sem vida diante de uma imensidão inóspita de água, completamente vulnerável, acendeu a comoção e indignação das pessoas, que gostariam de reparar aquilo, e reverter a sensação de que o socorro vinha tarde demais.

Cornelia Brinks, citada por Sontag no ensaio já mencionado escreveu sobre as imagens dos campos de concentração nazistas após a vitória dos aliados. Em uma analogia potente, ela chama essas imagens de ícones seculares, para enfa- 
tizar a sua importância no imaginário político criado pelos horrores do século XX. Ela compara essas imagens a ícones religiosos, não porque estejam indicando ou presentificando uma realidade transcendental e sacra. Ela os compara porque, de modo análogo, as imagens dos campos presentificam algo maior do que elas, algo envolto em gravidade, suprema importância e solenidade. As imagens se tornaram ícones porque fizeram história, porque as imagens dos campos estruturaram a visão contemporâneaque temos das atrocidades modernas. O que sentimos hoje em relação à violência fotografada é uma lição aprendida nos campos. Elas têm um apelo moral inquestionável, estão altamente disseminadas, e são imediatamente reconhecíveis. Como ícones do extermínio, elas inspiram temor, medo e compaixão, e representam o clamor do final de uma época e sua lição: "nunca mais essa destruição deve se repetir".

Ali, o passado está representado, mas seu impacto simbólico é tão grande que pode tornar aquele horror presente. A fotografia tem uma afinidade especial com a realidade, como uma emanação do referente, como disse a autora, citando Barthes. As fotos dos campos tornam os responsáveis imediatamente culpados e, de maneira mais sutil e difusa, provocam um senso de culpa no observador. O horror que as fotos inspiram é o horror do esmagamento do ser humano em seu opróbrio. Acredito que o uso que a autora faz da ideia de ícones seculares seja válida para pensar o caso presente, enquanto um "objeto de contemplação destinado a aprofundar o sentido de realidade de uma pessoa" (SONTAG, 2003, p. 319). Na imagem de Aylan, os horrores de uma guerra ocorrida em um lugar longínquo tornaram-se presentes para as pessoas que antes a ignoravam ou ainda mantinham dela uma distância política e afetiva.

Na Europa, França, Alemanha e Áustria se dispuseram a abrir suas fronteiras para os refugiados sírios que estavam chegando, e David Cameron declarou estar "profundamente comovido" com a morte de Aylan e prometeu "assumir suas responsabilidades morais". Uma força coletiva de solidariedade foi conclamada para "lidar com uma crise humanitária sem precedentes" e cidadãos europeus deslocaram-se até as fronteiras com seus carros para acolher os refugiados que estavam chegando. ${ }^{19} \mathrm{~A}$ foto causou um impacto moral tão grande que se falou em uma "mudança na política de imigração na Europa". A busca por um lugar seguro, longe da guerra, não poderia mais ser ignorada ou tratada como um problema político espinhoso pelos Estados europeus, mas deveria, sim, ser visto como uma obrigação moral diante de seres humanos em sofrimento. A vida de Aylan é uma vida passível de luto, uma perda que representa todas as

\footnotetext{
${ }^{19}$ Ver: <http://veja.abril.com.br/mundo/austria-e-alemanha-abrem-fronteiras-para-imigrantes-liberados-pela-hungria/>; <http://g1.globo.com/mundo/noticia/2015/09/fiquei-petrificada-diz-fotografa-que-fez-imagem-de-menino-sirio-morto.html >; e <http://g1.globo.com/ mundo/noticia/2015/09/apos-choque-com-foto-de-menino-morto-europa-busca-superar-divisoes.html>. Acessos em: 30 abr. 2017.
} 
perdas injustas da guerra, e o problema do refúgio passa a ser observado com olhos mais compassivos.

Sontag se pergunta se imagens chocantes podem despertar a consciência política das pessoas a ponto de fazê-las se indignarem com a guerra e promoverem ações éticas e políticas contra ela. Acredito ser cedo para avaliar se a foto icônica de Aylan promoveu ações nos dois sentidos, ético e político: na Europa, os imigrantes e refugiados encaram perseguições do Estado e de grupos neonazistas, sofrem com o frio e a fome nos campos criados para recebê-los, e conseguir o visto para viajar continua sendo um desafio. Pelo que pude perceber dos desdobramentos das jornadas e no enorme esforço de organizações e pessoas em ajudar os refugiados em suas necessidades e no trabalho de sensibilização de outros brasileiros, o pêndulo parece oscilar mais para a ação ética. Uma ação ética seletivamente motivada na direção de vidas precárias e, por isso, limitada por uma série de condicionantes, sobretudo de classe, raça e nacionalidade. Ao adentrar os meandros da militância do refúgio e da imigração em São Paulo, pude conhecer muitos refugiados congoleses, haitianos (que possuem visto humanitário) senegaleses e angolanos, além de imigrantes peruanos, colombianos e bolivianos. ${ }^{20}$ Há um desconforto público pela intensa visibilidade e assistência dos sírios e palestinos em detrimento de outros povos.

Entre essas pessoas, há uma denúncia de invisibilidade ou visibilidade negativa, que se expressa em descaso, repulsa ou mesmo violência racista e xenofóbica, com casos de assassinato de haitianos e congoleses. Entre essas nacionalidades, as pessoas que ganharam notoriedade e conseguiram se inserir no circuito humanitário-midiático são criticadas pelos que não conseguiram e permanecem no ostracismo. A impossibilidade de universalização da ajuda e visibilidade política aos mais necessitados alcança sua agudeza quando tal ajuda é oferecida aos refugiados e negada aos brasileiros nas ocupações. Pude ver isso acontecer na ocupação Leila Khaled, e ouvi relatos semelhantes na ocupação Cambridge, onde vivem muitos refugiados africanos, que me disseram se sentirem pressionados em relação a essa questão por outros moradores. A ideia inicial, que parecia muito potente politicamente, isto é, pessoas de diversas nacionalidades forçadas a se deslocarem por motivos distintos se encontrando em um espaço político e de moradia autônomo é comprometida, em parte, pela seletividade dos enquadramentos das vidas precárias. ${ }^{21}$

\footnotetext{
${ }^{20}$ Os deslocados no mundo hoje somam 65 milhões segundo dados da Acnur, a maior crise migratória desde a Segunda Guerra Mundial.

${ }^{21}$ Neste artigo, não discutirei os modos de enquadramento do Estado em relação ao imigrante/ refugiado. Contudo, é notável o trabalho das organizações voltadas a essa população na produção de sujeitos legíveis para o Estado, através da produção de documentos, narrativas e burocracias a que são submetidos diariamente. Sobre isso, ver o trabalho de Vanessa Perin (2013; 2014). Além disso, existe um desejo estatal pelo "imigrante produtivo", isto é, aquele que venha ocupar postos indesejados no mercado de trabalho.
} 
É muito importante frisar que, da parte de muitos profissionais e voluntários, sobretudo os que permaneceram árdua e persistentemente o seu trabalho, essa seletividade não ocorreu. Ao contrário, sempre procuraram universalizar a assistência e promover a visibilização das causas políticas das vidas das pessoas nas quais se engajaram. Falo em termos de uma tendência geral para enfatizar os modos de enquadramento que brotaram da viabilização da guerra na Síria e alguns de seus efeitos e impactos. O exame crítico desses enquadramentos é feito internamente e é sobre isso que gostaria de falar no próximo tópico.

\section{Agenciamentos}

Do ponto de vista político e cultural, uma ocupação formada parcialmente por refugiados palestinos apresenta uma novidade e um desafio. Ao contar da experiência da ocupação Leila Khaled para uma importante militante do MTST, ela se mostrou impressionada e disse que esse é um tipo de configuração com a qual os movimentos de moradia não estão preparados para lidar. As diferenças culturais, a dificuldade da língua e os problemas político-jurídicos concernentes ao refúgio e à imigração extrapolam os conhecimentos e metodologias do movimento de moradia. Some-se isso à intensa visibilidade dos refugiados e a presença de jornalistas e ONGs dentro das ocupações, e o problema ganha contornos potencialmente inflamatórios. ${ }^{22}$ Além disso, construir uma coletividade política a partir dos referenciais do movimento gera, para dizer o mínimo, muitos equívocos de tradução cultural. É muito difícil construir solidariedade entre as famílias se há uma intensa solidariedade e vontade política externa em ajudar e visibilizar os refugiados e pouca ou nenhuma em fazer o mesmo com as famílias brasileiras.

Mais do que refugiados da Síria, os palestinos que viviam em campos nesse país, constituídos em 1948 e 1976, vivem uma realidade política para além da guerra atual. "Uma cobra não dá o bote duas vezes", relatou-me Ammar, repetindo uma frase que ouviu de palestinos mais velhos na Síria. "Quer dizer que só se é refugiado uma vez. Eu sou refugiado da Palestina, e o responsável pelo meu exílio e todas as suas dificuldades é Israel.” Quando sonham em voltar para o seu país de origem, pensam em voltar para a terra de seus antepassados, a Palestina, e não para os campos de refugiados palestinos na Síria e no Líbano. Antes do direito à moradia, o Direito de Retorno, $\mathrm{Al} A w d a$, garantido pela resolução 194 e a pedra de toque da política palestina fora do país atualmente. Com todas as decepções políticas advinda dos Acordos de Oslo, ${ }^{23}$ o Retorno ainda é um desejo

\footnotetext{
${ }^{22}$ Pouco depois tomei contato com o Grupo de Refugiados e Imigrantes Sem-Teto (Grist), que nasceu dentro do Hotel Cambridge, uma ocupação do MSTC.

${ }^{23}$ Os acordos de paz firmados entre a OLP, representada por Yasser Arafat, e Israel, representado por Isaac Rabin. Neles, os palestinos que foram expulsos não são mais contemplados com o
} 
vivo e politicamente potente que move os refugiados palestinos, especialmente os que habitam os países próximos à Palestina.

A experiência política, cultural e afetiva da ocupação criou relações e ideias criativas para além da experiência de moradia. No começo de 2015, o restaurante palestino Al Janiah foi inaugurado por Hasan Zarif, do Movimento Palestina para Tod@s, e o comando da cozinha ficou a cargo de palestinos da ocupação. Desde o princípio da diáspora síria, a culinária árabe ${ }^{24}$ estava sendo o principal modo de inserção dos(as) refugiados(as) no mercado de trabalho, ${ }^{25}$ e a maior parte deles(as) estava aprendendo a cozinhar profissionalmente aqui no Brasil. Eles ficaram realmente impressionados com a intensidade com que paulistanos frequentam restaurantes, me perguntando se nós comíamos em restaurantes sempre ou sabíamos cozinhar. Não é costume na Síria a frequentação cotidiana de restaurantes, um hábito particularmente paulistano. Em princípio, eu frequentei o restaurante para ajudar no bar e de vez em quando no serviço das mesas, mas depois me tornei garçonete durante quatro dias da semana e passei a compartilhar da rotina do restaurante. É frequente o público que vai até lá usando kuffiya (lenço palestino) ou até mesmo perguntando se a temos para vender. Entre um pedido de cachaça e outro, ouviadas pessoas perguntas sobre a questão palestina, sobre os refugiados, e elogiosà criação do restaurante, ele mesmo um espaço de refúgio.

No ano de 2015, membros do Grupo de Refugiados Sem-Teto de São Paulo encontraram-se com membros do MOP@T no restaurante. A partir desse encontro, outras organizações foram chamadas e criou-se uma Frente Independente de Refugiados, que articula imigrantes e refugiados de África, América Latina, Caribe e Oriente Médio. Ela surgiu de uma necessidade premente de criar uma organização independente que não passasse pela mediação das ONGs de solidariedade, que até então ofuscavam o seu protagonismo. Além disso, lhes incomodava o modo como eram visibilizados nas mídias e diziam que faltava politizar o refúgio, isto é, mostrar às pessoas no Brasil os verdadeiros motivos de estarem ali, exiladas de seus países natais. O restaurante passou a realizar muitas atividades promovidas por refugiados e imigrantes, como o Dia Internacional do Refugiado, com a participação de artistas e venda de comidas congolesas e palestinas. Artistas haitianos e congoleses passaram a realizar apresentações no espaço, promovendo debates sobre a nova lei de migração e denúncias das injus-

Direito de Retorno, além de ser negada a soberania de Gaza e Cisjordânia.

${ }^{24}$ Isso não é propriamente uma novidade: a cidade tem uma longa relação com a comida árabe feita pela população libanesa que vive há quase um século no Brasil. Contudo, a maior parte dos restaurantes libaneses são caros e elitistas, um aspecto característico da relação que mantêm com a alimentação. O Al Janiah tem outra proposta: reunir memória palestina, afeto, música e política dentro de uma perspectiva mais esquerdista de resistência.

${ }^{25}$ Isso se deve a inúmeros fatores: dificuldade na revalidação de diplomas, escassez de trabalho, diferenças culturais, de idioma etc. 
tiças políticas ocorridas no Brasil e em seus países de origem.

A composição intercultural do restaurante, tanto de funcionários quanto do público que o frequenta, entrecruza realidades espaço-temporais muito distintas. Isso transforma a rotina das pessoas que ali passam seu tempo trabalhando, comendo ou bebendo, em uma composição cultural heterogênea. Qualquer um que entrasse na cozinha poderia dizer que não se encontrava no Brasil, a julgar pelo idioma falado, música, cheiros de comida e temperos estrangeiros, bem como os assuntos ali discutidos, as políticas da Síria, Irã e Turquia. A novela passando em um dos computadores também não poderia ser compreendida por um brasileiro, por exemplo. Os hábitos culturais observados também são outros, mas incluem os brasileiros ali presentes em seus códigos.

$A b o$ Thaier ${ }^{26}$ é um dos poucos que já trabalhava com comida, sendo a carne de shawarma a sua especialidade. Enquanto $A b o[p a i]$, ele é sempre o primeiro a perguntar se nós - as meninas que trabalham no restaurante - já comemos e se queremos jantar. E é quem me procura pra pedir que cuide das matrículas de adolescentes palestinos e sírios nas escolas brasileiras. É ele quem normalmente prepara o shay preto adoçado e o café com cardomomo, qahuww e hein, servindo todos os copos de uma vez. Em uma cozinha palestina, o café, o chá, a comida e o cigarro são compartilhados. Quando um bebe, bebem todos. Aprendi isso ao vê-lo repetidamente entrar no salão com dois copos nas mãos, nos procurando para entregar nossas bebidas. Depois descobri que não fazer isso, isto é, servir comida e bebida para todos os presentes, é $a i b$, "uma coisa que você não pode fazer", uma espécie de falta de etiqueta entre eles.

Já Raame foi barbeiro por quinze anos antes da guerra. É a pessoa com quem mais converso sobre religião e por quem eu soube, um dia, de um dos sentidos importantes do pão - pita - para eles. Eu havia jogado um resto de pão que sobrara das mesas no lixo e fui repreendida por ele, que o pegou na mão, me chamou e disse "jogar pão no lixo é haram, Helena”. Foi assim que descobri um cesto separado para as sobras de pão na cozinha que não havia visto antes ${ }^{27}$ e que então passei a usar. "Em um país árabe, se um pedaço de pão cai no chão, é comum a pessoa se abaixar, beijá-lo e comê-lo em seguida."

Durante o mês do Ramadan, todos eles ficaram mais recolhidos na cozinha, interagindo menos com os brasileiros. Eu perguntei uma vez ao Raame se podiam realizar as orações no restaurante (que comercializa álcool) e ele me respondeu que sim, "só na cozinha". Ainda que um deles tenha me perguntado um dia, conversando do lado de fora do bar e vendo a interação embriagada de brasileiros, se eu achava que a cozinha e a comida que faziam eram haram, por

\footnotetext{
26 "Pai do Thaier". Thaier é o nome de seu filho homem mais velho. Ao se tornarem pais, passam a ser chamados assim, sempre a partir do nome do filho homem, ainda que este não seja o primogênito.

${ }^{27}$ Raraam: pecado, tabu. As sobras serão dadas aos animais depois.
} 
conta do álcool servido no salão. A mistura entre os ambientes e o dinheiro ganho os torna impuros, ainda que beber álcool na cozinha seja um hábito evitado pelos que bebem.

Tive a oportunidade de fazer as refeições do Ramadan com eles no próprio bar. O suhoor, a primeira refeição frugal antes de se iniciar o jejum, realizada às vezes no restaurante, em razão de algum evento que tenha durado até mais tarde. Enquanto as pessoas dançavam e bebiam do outro lado do corredor que separa a cozinha do salão, comíamos homus, pão, babaganoush, salada de tomate e tomávamos shay. Pela ocasião, senti estar compartilhando mais da refeição e notei que me trataram com maior intimidade. Quando peço mais shay, começam a rir, e um deles diz "agora Helena árabe”. Ao final da refeição, mostram-me fotos e vídeos da família, que sei que revisitam sempre, especialmente durante o Ramadan. Já o Iftar, a quebra do jejum, feito um dia no restaurante, com a preparação de um carneiro e a ajuda de palestinas que vivem na ocupação, excepcionalmente convertido em um ambiente halal, ${ }^{28}$ sem consumo de álcool.

Nem todos os palestinos se abstêm de álcool, mas as regras de compartilhamento do bar são diferentes das da cozinha, o que já provocou conflitos acalorados no balcão, com troca de empurrões e palavrões em árabe, alguns dos quais já consigo distinguir. Uma hora depois, no entanto, parte dos garotos advertidos já está dançando e se divertindo na pista. Os que consomem álcool têm menos pudores com as brasileiras, conversando e flertando com as clientes. Contudo, guardam o pudor característico de sua criação, dissimulando a vergonha através de uma tenaz demonstração de virilidade e coragem. Às vezes, quando estamos vendo novela e fumando diante do computador de um deles, dão uma risadinha envergonhada em nossa direção diante de cenas de amor, ou, então, quando uma mulher em cena cobre-se com um hijab para receber um homem. Todos se esmeram em nos oferecer cigarros, em nos acompanhar de perto em saídas à rua ou em nos substituir no trabalho braçal.

Compartilhar não só do trabalho e da luta, mas da comida, do chá e do cigarro aproximou-nos e forjou as condições para brasileiros e palestinos participarem mais plenamente das relações ali construídas (CARSTEN, 1995). Se a língua nos limita, a comida, o cigarro, a dabka e o shay permitem que nos relacionemos dentro dos códigos culturais, de afeto e cuidado dos(as) palestinos(as). Isso certamente é verdade para as pessoas que frequentam o Al Janiah, não só compostos de brasileiros, mas de outros imigrantes e refugiados que vão lá para fazer política e compartilhar daquilo que Bhabha (1998) chama de tempo de reunião, da estranha fluência da língua do outro, reunindo memórias de outros mundos, outras vidas, o passado, reunindo os povos da diáspora. Foi ali que vi um congolês denunciar a diferença entre refugiado branco e refugiado negro e

${ }^{28}$ Permitido e prescrito, segundo as regras da religião. 
a hipocrisia do racismo brasileiro, enquanto os clientes bebiam tangawisi, o suco feito por refugiados da guerra do coltan, material presente em nossos celulares. Ou um filho de libanês me perguntar com os olhos brilhantes se eu não tinha um pouco de zaatar e azeite para colocar em cima do laban, que ele levou de volta à casa da avó. O lugar em que vi uma chilena polvilhar pimenta mapuche no laban e rir faceira da transgressão cometida quando pega em flagrante.

Lá é onde se discute política no salão, no balcão e na cozinha, onde podem ser ouvidas palavras como "golpe”, "Temer”, "Erdogan”, "Khomeini', "Bashar', "Cáritas", "Conare” e "refúgio” em muitas línguas. A Palestina ali aparece nos mapas, nas kuffiyas que clientes usam ao irem comer no restaurante, nas músicas, nos pulsos e pescoços dos palestinos, nos corpos, muxoxos e estalos de língua quando querem manifestar contrariedade.

A criação do restaurante $\mathrm{Al}$ Janiah, a formação da coalizão de migrantes e refugiados, bem como os encontros entre organizações de apoio a migrantes e refugiados, movimentos de moradia e outros movimentos autonomistas, artistas brasileiros, árabes, organizações de cultura árabe, especialistas em política do Oriente Médio, internacionalistas e intelectuais de esquerda, se tornaram possíveis a partir da experiência primeira da ocupação Leila Khaled. As imagens do refúgio propaladas pela cobertura midiática após a repercussão da foto do menino Aylan, ainda que controversas, projetaram publicamente a ocupação e tornaram possível a conexão entre mundos distintos. Se a relação entre refugiados e brasileiros foi inicialmente colocada em termos assimétricos pelos enquadramentos de guerra, a visibilidade e as relações engendradas pelos mesmos foram recolocadas em termos de reciprocidade mais simétricos pelos próprios, na forma de uma indagação crítica. Mas, também, na forma de arte e culinária, modos mais potentes e simétricosde se relacionar, além de culturalmente mais ricos do que os oferecidos pela imagem de vulnerabilidade que acompanha o refúgio.

\section{Referências bibliográficas}

BRINKS, Cornelia. Secular Icons: looking at photographs from nazi concentration camps. History\&Memory, v. 12, n. 1,primavera/verão, 2000.

BHABHA, Homi. O local da cultura. Belo Horizonte: Ed. UFMG, 1998.

BUTLER, Judith. Quadros de guerra. São Paulo: Civilização Brasileira, 2015.

CARSTEN, Janet. The Substance of Kinship and the Heat of the Hearth: feeding, personhood, and relatedness among Malays in Pulau Langkawi. American Ethnologist,v. 22,n. 2,mai. 1995, p. 223-41.

FILADELFO, Carlos. A construção do centro de São Paulo como arena política 
dos movimentos de moradia. Ponto Urbe - Revista do Núcleo de Antropologia Urbana da USP, n. 6, ago. 2010.

PERIN, Vanessa.A burocracia não acaba nunca. Reflexões sobre a composição do sujeitorefugiado por entre documentos, programas de assistência e organizações. Revista de Antropologia da UFSCar, v.5, n.2, jul.-dez.2013, p.83-94.

Um campo de refugiados sem cercas: etnografia de um campo de um aparato de governo de populações refugiadas. Horizontes Antropológicos, Porto Alegre, ano 20, n. 41, jan./jun. 2014,p. 303-330.

SAID, Edward. Orientalismo: o Oriente como invenção do Ocidente. São Paulo: Companhia das Letras, 2003.

SONTAG, Susan. Diante da dor dos outros. São Paulo: Companhia das Letras, 2003.

autora Helena de Morais Manfrinato

Graduada em ciências sociais pela Universidade Estadual Paulista (Unesp), mestre em antropologia social pela Universidade de São Paulo (USP) e doutoranda do Programa de Pós-Graduação em Antopologogia Social da USP.

Recebido em 07/04/2017

Aceito para publicação em 07/04/2017 